This is an Author's Accepted Manuscript of a chapter in Jorge Diaz Cintas, Anna Matamala, Joselia Neves (eds.) New Insights into Audiovisual Translation and Media Accessibility. Media for All 2. Amsterdam / New York: Rodopi, 123-136, available here:

http://www.rodopi.nl/functions/search.asp?Bookld=ATS+33

\title{
Translating postmodern networks of cultural associations in the Polish dubbed version of Shrek
}

Agnieszka Chmiel

\section{Introduction}

Poland is a typically voiceover country with few films translated with other audiovisual translation (AVT) techniques, such as dubbing or subtitling. However, the viewers' generally negative approach to dubbed films changed slightly alongside the immense popularity of the Polish dubbed version of Shrek (Andrew Adamson and Vicky Jenson, 2001). This paper focuses on examining, comparing and juxtaposing selected networks of cultural associations created by original (US culture-oriented) and translated (Polish culture-oriented) utterances of the film characters in Shrek. The analysis of original and translated dialogues seeks to answer a host of questions: What do Polish viewers lose in the domesticated dubbing version of Shrek? Do they lose anything at all or would they be able to decipher most of the source culture allusions in the original text? What do Polish viewers gain? How are the discrepancies between messages sent through the domesticated audio channel and the non-domesticated unadjusted visual channel perceived? For the purpose of the analysis, the dubbed text is set in the context of screen translation in Poland and the Polish polysystem of films, the nature of audiovisual translation operations and the intertextuality of the original work.

\section{Screen translation in Poland}

Screen translation in Poland, as in many formerly communist states in Central and Eastern Europe, is mainly based on voiceover, a cost-effective audiovisual translation technique that deafens actors' voices with an emotionless reading by a narrator. Voiceover is used for virtually all translations on public television regardless of the genre - be it a feature film, a documentary or a quiz show - and is predominant on non-public TV channels. In cinemas, subtitling is used for the majority of productions. Dubbing is applied solely to TV shows and films addressed to children (both on TV and in cinema). Additionally, when films are released on DVD, their voiceover versions are now usually available. In fact, Polish DVD releases of foreign films used to be advertised by focusing on the availability of the voiceover version as added value. This, as unbelievable to the viewers from non-voiceover countries as it may be, shows that Poles are so accustomed to voiceover that they simply disregard its disadvantages when compared to subtitling.

There is very little data as regards types of AVT applied by various Polish mass media. According to a 1991 study by the European Institute for the Media, 100\% of TV programmes in Poland were translated via voiceover while $100 \%$ of films screened in cinemas were subtitled (Dries, 1995). Since then, the situation has not changed much and television shows - at least the ones offered by TVP, the Polish national broadcaster - are still predominantly voicedover while cinemas use subtitling overwhelmingly and dubbing only for films addressed to children.

According to a survey conducted in 2002 , voiceover is preferred by $50.2 \%$ of Poles, dubbing is favoured by $43.3 \%$ and subtitling is chosen by $8.1 \%$ of Poles (Bogucki, 2004). Polish viewers seem to be well accustomed to voiceover and rather unwilling to change their preferences. This might be partially due to the fact that early dubbing attempts in the 1980s were rather unsuccessful and strengthened the market position of voiceover. Private broadcasters did not have enough expertise and were not willing to allocate sufficient funds to produce professional dubbing. Moreover, when attempting to introduce dubbing and subtitles on television, the Polish national broadcaster met with a lot of criticism on the part of the viewers (Garcarz, 2006:115). 
This is an Author's Accepted Manuscript of a chapter in Jorge Diaz Cintas, Anna Matamala, Joselia Neves (eds.) New Insights into Audiovisual Translation and Media Accessibility. Media for All 2. Amsterdam / New York: Rodopi, 123-136, available here:

http://www.rodopi.nl/functions/search.asp?Bookld=ATS+33

Dubbing has been considered by many viewers as something 'damaging', an obstacle that detaches the viewer from the original voice and acting. The general criticism raised against dubbing in Poland was in its nature similar to that mentioned by Whitman (1992:118, in Chaume, 2003:104) in the early 1990s: "Artificiality is one of the main faults pillored in denouncements of dubbed versions: the audience can hear that this is not an original. Dubbed language simply does not correspond to the way normal people talk". Additionally, when poorly translated, entertainment programmes lost their main popularitygenerating factor.

Dubbing is also widely criticised by viewers on the internet. According to many negative opinions expressed last year on various forums frequented by fans about the poor quality dubbing of The Simpsons - screened by TV Puls, one of Polish non-public broadcasters - the low popularity of this otherwise immensely successful cartoon was precisely due to the irritating and less than amusing translation. In fact, low popularity ratings and criticism of the dubbed version forced the broadcaster to discontinue the series.

These open criticisms are somehow at a variance with the most recent survey conducted among Polish viewers. According to the 2005 opinion poll, their preferences changed slightly as compared to the 2002 results with dubbing ranking first (46\%), followed by voiceover (45\%) and subtitling (5\%) (Garcarz, 2006). This trend might show that Polish viewers have started noticing the advantages of dubbing as an AVT technique over voiceover in general but are also dissatisfied with the quality of many domestic dubbing productions. It remains to be seen if this change in preferences is the beginning of a longterm trend, also in the context of the very successful dubbing of Shrek to be analysed below.

An overview of listings of Polish cinemas in one large city (Poznań) done by the author in April 2006 and repeated in November 2008 shows that only approximately $20 \%$ of films are dubbed; mainly films directed at young audiences or families with children. However, as mentioned above, the perception of dubbing has changed slightly thanks to excellent dubbed versions of animated movies directed mainly to children, but also - due to their postmodern intertextual nature - to adults. A major breakthrough came with the Polish dubbed version of Shrek (original version written by Joe Stillman, Roger S.H. Schulman, Ted Elliott and Terry Rossio; Polish version by Bartosz Wierzbięta), released in 2001. The dubbed version of this film will be analysed in more detail in the second part of this chapter. In the first part, the analysis will be preceded by more general remarks about the scope of AVT, the position of dubbed movies in the Polish film polysystem and the postmodern nature of popular culture.

\section{AVT - operations on semiotic complexes}

Audiovisual translation, especially when analysed in the context of cultural and postmodern intertextuality, should not be treated as an operation on language and culture only. According to Tomaszkiewicz (2006:98), AVT involves much more than operations between the source language and the target language (on the linguistic level only), between the source message and the target message (i.e. involving communication, context, utterance, intentionality, etc.), or even between the source text and the target text. She claims that due to its intersemiotic nature, AVT includes operations between the source semiotic complex and the target semiotic complex. It is a specific type of translation that combines elements of a traditional interlingual and intersemiotic translations (ibid::100). Although the translator changes only the verbal layer of the film, the translation has to fit the whole semiotic context of the film and the semiotic complex of the target culture.

Zabalbeascoa (1993:222-3, in Chaume, 2003:70) applies a similar approach to dubbing, by claiming that "the translation (a process performed only on the verbal signs) is only one part of the dubbing process (which should take into account verbal and nonverbal signs); the words are just part of the final product". 
This is an Author's Accepted Manuscript of a chapter in Jorge Diaz Cintas, Anna Matamala, Joselia Neves (eds.) New Insights into Audiovisual Translation and Media Accessibility. Media for All 2. Amsterdam / New York: Rodopi, 123-136, available here:

http://www.rodopi.nl/functions/search.asp?Bookld=ATS+33

In his pragmatic plot-oriented approach to translation in dubbing, Luyken et al. (1991:162) suggest that one should not translate sentence by sentence, but rather scene by scene. The scene should be treated as a translation unit. Such an approach gives the translator more freedom since the objective is to provide the faithful translation of a scene, which means that omissions, additions and shifts between sentences within a scene are perfectly acceptable. As it will be shown below, the translator of Shrek did apply the above mentioned theoretical assumptions in his global strategy.

\section{The Polish polysystem of films}

When analysing translations of any artistic works, it is very useful to put both the former and the latter in the context of the target culture artistic landscape. Only then can it be seen if the translated work under scrutiny complies with the established norms, breaks certain rules or sets new standards if there have been none previously. In the case of AVT, it is helpful to resort to Even-Zohar's (1978) literary polysystem theory as applied by Díaz Cintas (2004) to films. A film polysystem, as one of the "semiotic systems that co-exist dynamically within a particular cultural sphere" (Díaz Cintas, 2004:22) includes national and translated products and relationships among them. Translations "shake off the mantle of a secondary, deficient product" and are "in principle at the same social and cultural level as the national ones" (ibid::24). This statement is quite crucial for current deliberations since, as we hope to show, the analysed film has shifted in the Polish polysystem from the location traditionally reserved for dubbed films.

The Polish polysystem includes, apart from national films, foreign films that are translated mainly using subtitles (in the cinema) or voiceover (on television) with US films enjoying a central position, especially in the popular culture. Dubbed films used to be rather peripheral due to poor quality dubbing. Therefore, no standards or norms have been developed as regards this type of AVT in Poland, as opposed to other countries with long established dubbing traditions, where isochrony can be a flexible restriction like in Italy or one of the major dubbing constraints like in Spain (Chaume, 2004:47). Additionally, there is a high level of acceptability of Anglicisms and foreignisation in Poland and some movie titles are not even translated (e.g. Good Night and Good Luck or The Flintstones, the latter being a curious case since the TV cartoon was also very popular in Poland and it had a translation well established in popular culture: Jaskiniowcy [The Cave People]). This overall acceptance of foreignisation might stem from generally pro-American sentiments that are strong across Poland or from the viewers' previous experiences with very bad or strange translations of some film titles (e.g. Reality Bites translated as Orbitowanie bez cukru (sic!) [Orbiting Without Sugar] or Dirty Dancing translated as Wirujący seks (sic!) [Spinning Sex]). It is very interesting to analyse the dubbed version of Shrek against this background for the following three reasons: it is the first immensely successful example of a dubbed movie that is no longer peripheral to other translated movies with subtitles or voiceover; it has set some standards as regards dubbing strategies; these strategies are based mainly on domestication, which is surprising in the context of the wide acceptability of foreignisation in Poland.

\section{The postmodern nature of popular culture}

Before moving on to the analysis of the translation of Shrek to see how postmodern networks of cultural associations and various intertextual allusions were rendered by the Polish translator, let us ponder shortly on the nature of modern popular culture of which this film is such an excellent example. According to Johnson (2005:xi), popular culture has grown more complex and intellectually challenging over the past years. Modern works of popular culture, be it computer games, television series or films, are more sophisticated and present us with increasingly demanding cognitive challenges. 
This is an Author's Accepted Manuscript of a chapter in Jorge Diaz Cintas, Anna Matamala, Joselia Neves (eds.) New Insights into Audiovisual Translation and Media Accessibility. Media for All 2. Amsterdam / New York: Rodopi, 123-136, available here:

http://www.rodopi.nl/functions/search.asp?Bookld=ATS+33

Films abound in intricate narrative paths, multiple layers of information built into the plots, intertextual references and allusions to other works and to reality. Johnson (2005) compares the structure of TV crime series from the 1970s (such as Starsky and Hutch) with their younger counterparts (such as The Sopranos) or popular children's films (Bambi from 1942 and Mary Popins from 1964) with more recent box office hits (Monsters Inc. from 2001 or Finding Nemo from 2002). The analysis shows that current series and films include more complex narratives with multiple plots and threads, a greater number of characters with more developed social networks and more pronounced intertextuality.

The upward trend visible in more complex narratives, called the Sleeper Curve by Johnson (ibid.), is much visible in children's films, such as Toy Story, Shrek, Monsters, Inc. or Finding Nemo. According to Johnson (ibid::127): "creators of these recent films build distinct layers of information into their plots, dialogue, and visual effects, creating a kind of hybrid form that dazzles children without boring the grownups". While visual allusions may be perfectly detectable to native and foreign audiences (such as the jocular allusion to Matrix in Shrek or to Beverly Hills Cop in Shrek 2), postmodern intertextual networks of cultural associations created on the linguistic level set a great challenge to audiovisual translators who cannot resort to lengthy explanations or footnotes. This challenge is also observed by Agost (2004:66), who states that: "if the analysis of culture reveals a complex network of ideas and highlights a relationship between the various systems, the intercultural situation that translation represents is an additional difficulty". Set in this context, Shrek is a perfect object of study to see how the author of the dubbed script managed to overcome technical and linguistic constraints and to weave the intertextual network of domesticated or foreignised allusions into the fabric of the dialogue exchanges.

\section{The translator's strategy}

The text for the dubbing version of Shrek was created by Bartosz Wierzbięta who is now a well-known audiovisual translator and dialogue writer. He tackled the challenge presented by the postmodern, intertextual film by applying a target culture adaptation strategy. Tomaszkiewicz (2006:202) claims that animated films translated by Wierzbięta are a very good example of domesticated dubbing:

We are facing a new dimension of film dialogues that are friendly to Polish viewers, i.e. dialogues that are fully understood thanks to their references to our linguistic and cultural background. A skilful translator, such as Wierzbięta, smuggles some information that refers to the Polish reality into translated dialogues. Thus, foreign characters are assimilated for the viewers. As a result, the translator introduces a national dimension to the dialogues and creates additional comic effects (my translation and emphasis).

Therefore, the criterion of fidelity seems to have lost its priority when confronted with other functions played by the dubbed film.

Zabalbeascoa (1997:336) lists criteria and restrictions that refer to the translation of television situation comedies. Some of them, such as the following, pertain also to the translation of children's films and comedies:

1. popularity ratings - the commercial dimension of the film and its translation is important;

2. the translation should be funny, entertaining and should elicit laughter;

3. it should 'integrate the words of the translation with other constituent parts of the audiovisual text';

4. implicit and explicit allusions to other TV programs or films work only if they are part of the required 'shared knowledge'. 
This is an Author's Accepted Manuscript of a chapter in Jorge Diaz Cintas, Anna Matamala, Joselia Neves (eds.) New Insights into Audiovisual Translation and Media Accessibility. Media for All 2. Amsterdam / New York: Rodopi, 123-136, available here:

http://www.rodopi.nl/functions/search.asp?Bookld=ATS+33

As it will be shown, the translation strategy and solutions applied by the translator of the analysed film comply with the above priorities and restrictions. Wierzbięta (in Wojtowicz 2002:online) presents his overall translational strategy as follows:

Dialogues have to be comprehensible to the Polish audience; thus, it is not always appropriate to produce a complete equivalent of the original dialogues. If nuances of the original language and puns are not funny, they should be adapted to the Polish reality. The development of my translation skills meant that I became aware of the fact that I can enjoy more freedom and that I can afford more freedom. (...) It is not about the Polish text being the perfect reflection of the original text. What counts is that the text is synchronized, attractive and comprehensible. I know from my own experience that the more detached the Polish dialogue is from the original, the better it is. It is not a rule but the movies with the greatest number of such differences were the most popular (my translation and emphasis).

The translational equivalence is thus subjected to domestication. The text has to be first of all attractive, entertaining, easy to understand by the target audience, and only then faithful to the original. Wierzbięta's most favourite strategies include: adaptation, addition and compensation. They will be discussed in more detail in the subsequent sections.

The translator's freedom in translating an animated film is further justified because of a special status of the film as a work of art. When watching a dubbed film, viewers agree to two illusions, the first being 'the willing suspension of disbelief' (a term coined and originally applied to poetry by Coleridge 1817/1985:312) and the second being 'the suspension of linguistic disbelief' (Romero Fresco, 2006). The former pertains to any work of art. In the case of films it means that viewers accept the depicted world as real and look past certain limitations of the film as a medium. The latter pertains to the language spoken in dubbed films. Even if a film is set in the USA, the viewers consent to the illusion that the characters speak Polish, German or French and that the given language is natural to them. The suspension of the linguistic disbelief is even easier to obtain in an animated film, such as Shrek. Characters are not real and the plot is not set in any real country. Thus, it is easy for the viewers to believe that the characters speak fluent Polish and that some of them sound just like very famous Polish actors. The illusion created by the animated film gives more freedom to the translator. Since the viewers accept the fact that the characters speak Polish, they will also suspend their disbelief in the fact that the characters naturally allude to Polish reality in their conversations.

\subsection{Adaptation}

The original dialogue includes numerous allusions to films, fairy tale characters and other source culture-specific items. Their inexhaustive list includes: The Matrix, Cinderella, Big Bad Wolf, Three Little Pigs, Beverly Hills Cop, Robin Hood, Pinocchio, Sleeping Beauty, The Dating Game, and The Muffin Man. Some of these films or characters are part of the 'shared knowledge' refered to by Zabalbeascoa (1997:336). In such cases, the translator simply resorts to using well-established translations such as Pinokio [Pinocchio] and Śpiąca Królewna [Sleeping Beauty]. The problems arise when the culture-specific knowledge is not shared and the translator must adapt the source culture to the target culture and trigger a comic effect by creating completely new allusions and intertextual networks of postmodern associations.

One of the examples is a song sung by the flying Donkey that alludes to Dumbo, a flying elephant well-known to US children. Instead, the Polish version introduces a completely different allusion, not to a character of children's movies and the related song, but to a song performed by Jerzy Stuhr, the actor playing Donkey in the Polish version of 
This is an Author's Accepted Manuscript of a chapter in Jorge Diaz Cintas, Anna Matamala, Joselia Neves (eds.) New Insights into Audiovisual Translation and Media Accessibility. Media for All 2. Amsterdam / New York: Rodopi, 123-136, available here:

http://www.rodopi.nl/functions/search.asp?Bookld=ATS+33

Shrek. Jerzy Stuhr is much appreciated by Poles mainly for his comic characters. In 1977, he performed a song entitled Śpiewać każdy może [Anyone can sing] at the Polish Song Festival in Opole. The lyrics convinced the listeners that anyone can sing, no matter if the singing is good or bad, and Stuhr's singing was deliberately bad to create a comic effect. He plays a person who cannot really sing but is sure of his talent and has to give vent to it for fear of suffocation. The song is very popular in Poland and the title (anyone can sing) has been used in many contexts and talent shows. By activating a whole network of cultural associations, this substitution is very entertaining to the Polish adult audience.

The dubbed dialogue exchanges abound in Polish culture-specific references. The original allusion to a children's song about a 'Muffin Man' who lives on 'Drury Lane' is completely opaque to the Polish audience and is thus replaced with an allusion to cartoon characters Żwirek and Muchomorek. 'Parfaits' mentioned by Donkey are substituted with kremówki, a typically Polish cake that again triggers a network of entertaining associations, including even the childhood memories of Pope John Paul II, who largely contributed to the immense success of kremówki on the Polish market by reminiscing about them at one of his televised meetings with thousands of youths during his pilgrimage to Poland. The majority of the Polish audience would not know that 'Heimlich manoeuvre' mentioned by one of the characters is an abdominal thrust used to prevent choking. Thus, it is replaced with a phrase: Czy jest na sali lekarz? [Is there a doctor here?] that is fixed in Polish and sometimes used in jokes.

The above examples of translational adaptations show that some Polish solutions include even richer and funnier allusions than those in the original script and they definitely create different networks of postmodern associations. When evaluated according to Zabalbeascoa"s criteria for the translation of entertainment shows, these solutions seem to be very efficient and successful in evoking intended comic effects.

\subsection{Addition or compensation?}

Apart from the domesticated translations analysed above, the translator frequently resorted to adding to the translated text elements absent in the orginal. An addition is considered by Tomaszkiewicz (2006:206) as a translation error that involves an unjustified introduction in the target text of unnecessary information or stylistic effects not present in the source text. The domesticated dubbed version of Shrek in Polish abounds in unfaithful translations or additions of short linguistic items and even whole lines. In accordance with Luyken's et al. (1991) pragmatic approach to dubbing mentioned earlier, the translator justifies his approach in the following way: "If I have no good idea for translating a funny line, it's not crucial for me to have the Polish viewer laugh exactly at the same time as the American viewer. Let the Polish viewer laugh two lines later when there is nothing funny for the American viewer but there is something that could be a source of laughter for the Polish viewer" (in Wojtowicz, 2002: online, my translation). It remains to be seen if additions in the dubbed version should be treated as errors or rather a manifestation of a key translation strategy, i.e. compensation. What follows is an analysis of selected examples to settle the above issue.

Example 1

Shrek: Grab your torch and pitchforks.

Jontek, łap za widły. [Jontek, grab your pitchfork.]

The translator adds a name here, Jontek. This is an allusion to a famous Polish opera, Halka by Moniuszko, in which Jontek was one of the main characters of a rather impetuous nature. Humour in this line comes from the unexpected use of an old Polish name of an opera character in the film's context. 
This is an Author's Accepted Manuscript of a chapter in Jorge Diaz Cintas, Anna Matamala, Joselia Neves (eds.) New Insights into Audiovisual Translation and Media Accessibility. Media for All 2. Amsterdam / New York: Rodopi, 123-136, available here:

http://www.rodopi.nl/functions/search.asp?Bookld=ATS+33

Example 2

Pinocchio: Oh, gosh, no one invited us.

Hej, ty, no nie bądź taki drewniak.

[Hey, you, don't be such a stiff.]

The sense of this line is changed completely and a pun - a wooden character accusing someone of being stiff - is introduced to compensate for other comic effects present somewhere else in the original film and lost in translation.

Example 3

One of the three little pigs: He huffed and he puffed and he... signed an eviction notice..

Dmuchał, chuchał i zarządził, świnia, eksmisję.

[He huffed and he puffed and he... signed an eviction notice, what a pig.]

As in example 2, the pun, in this case related to a pig, is not present in the original and is deliberately added by the translator for a comic effect.

Example 4

Shrek: All right. You're going the right way for a smacked bottom.

Słuchaj, jeszcze chwila, a otworzę wytwórnię [Listen, you do that once again and I'll open a salami. salami production plant.]

This threating statement is used in the film by Shrek in his conversation with Donkey. Salami is known in Poland as a sausage made originally of horse meat. However, it was quite common in the communist Poland to manufacture products of substitutes due to the overall scarcity of goods. Thus, the inference here is that donkey meat can be a good substitute for horse meat, making the utterance funny to the Polish audience. As reported by the translator himself (in Wierzbięta, 2002), this phrase was a bone of contention with the representative of the US major supervising the Polish dubbing production. Example 5 below can be seen as an extreme instance of the translator's freedom:

Example 5

Donkey: ---

Idę po precelki.

['’ll get some little pretzels.]

The original character says nothing, while the dubbed character has been given a new line. The synchronisation requirement is fulfilled because the character's lips are not visible during this utterance. The only justification of such an addition is that it actually compensates for lost comic effect somewhere else in the film, either before or after that added line. Polish morphology allows for the creation of a variety of diminutives by resorting to suffixes. When used often, as is the case in the Polish version of Shrek, diminutives can create a comic effect. This is what happens in this particular instance in which pretzels are used in the diminutive form. Additionally, the (ab)use of diminutives can be seen as an allusion to the distinctive speaking style of Maks, a character from the unforgettable 1984 Polish comedy entitled Seksmisja and directed by Juliusz Machulski. Maks was played by actor Jerzy Stuhr, whose many comic lines are still alive in the Polish popular culture. As mentioned above, Jerzy Stuhr is the voice talent behind Donkey, and it is this duality that enables adult Polish viewers of Shrek to easily recognise the reminiscences of Maks in Donkey.

Example 6 
This is an Author's Accepted Manuscript of a chapter in Jorge Diaz Cintas, Anna Matamala, Joselia Neves (eds.) New Insights into Audiovisual Translation and Media Accessibility. Media for All 2. Amsterdam / New York: Rodopi, 123-136, available here: http://www.rodopi.nl/functions/search.asp?Bookld=ATS+33

Donkey: I'm right behind ya.

A co tu będę siedział? [Why would I sit around here like that?]

This line is an allusion to a very popular line from another well-known Polish comedy Psy. In one scene, an unpopular rookie cop is addressed by his older colleagues renowned for bending the rules in the following way: "What are you looking at? We're not here" and replies: "Then I'll go. Why would I sit around here like that alone?"

Example 7

Donkey: Listen, keep breathing!

Pamiętaj, wdech i wydech!

[Remember, breathe in and breathe out!]

This phrase alludes a nasty blonde joke. In the joke a blonde refuses to take off her headphones while at a hairdresser's. The irritated hairdresser finally takes the headphones off the blonde's head and she drops dead. Shocked, the hairdresser picks up the headphones to check what the blonde was listening to and is even more surprised to hear: "Remember, breathe in and breathe out!" Such jokes were very popular in Poland at the time the dubbing was produced.

The following line alludes to TV commercials of beer in Poland:

Example 8

Shrek: Can't we settle this over a pint?

Może omówimy to przy bezalkoholowym?

[Can't we settle this over alc-free beer?]

When a ban was introduced on the advertising of alcohol on television many beer producers counteracted by launching alcohol-free lines of their most well-known brands and advertising them legally. However, in a typical tongue in cheek twist, the producers made it obvious in their commercials that alc-free beer was not really what the advertising campaign was all about and people endorsing alc-free beer in the commercials could be seen winking an eye at viewers when saying 'alcohol-free'.

These examples show that the additions are justified and should be considered as instances of a compensation strategy, in which the translator has opted for a pragmatic approach. He clearly uses scenes, rather than sentences, as translation units and takes into consideration the whole intersemiotic complexity of audiovisual translation when deciding on his solutions.

Obscure source culture allusions are lost in translation and replaced with target culture allusions that trigger new intertextual values. However, certain elements of the original dialogue, like accents, do get lost irrecoverably. Such is the case of Shrek's Scottish accent that was not replaced with any Polish regional accent, perhaps because of the smaller regional variations in Polish and the different associations assigned to regional accents.

\section{Conclusions}

The above analysis shows that the function of the translated film, i.e. to activate entertaining and comic effects, has been preserved by replacing some source culture elements with domesticated elements. The loss of source culture allusions is not damaging since they would be largely undecipherable to Polish viewers. By compensating and introducing target culture oriented solutions the intricate intertextual network of allusions in the original has also been recreated in the target culture, thus maintaining the intended effect. 
This is an Author's Accepted Manuscript of a chapter in Jorge Diaz Cintas, Anna Matamala, Joselia Neves (eds.) New Insights into Audiovisual Translation and Media Accessibility. Media for All 2. Amsterdam / New York: Rodopi, 123-136, available here:

http://www.rodopi.nl/functions/search.asp?Bookld=ATS+33

The translator's overall approach turned out to be immensely popular and the successful domesticated dubbing of Shrek seems to have introduced certain shifts in the Polish polysystem of films when it comes to dubbed animations. As mentioned by Urbańska (2004, in Tomaszkiewicz, 2006:203, my translation): "the technique of polonization has in recent years become much desired and expected not only by the audience, but also by producers. [...] All translators of film dialogues are now required to polonize original film versions". Hence, dubbed animations have acquired a more central position in the polysystem and certain norms, standards and audience expectations have been identified and followed in subsequent productions. Thanks to the successful translation of Shrek, the previously negative opinion about dubbing held by most Polish viewers transformed into an enthusiastic one, as reflected in the results of the 2005 survey on AVT preferences among Polish viewers mentioned in the initial part of the paper (Garcarz, 2006).

Despite obvious advantages of dubbing over voiceover in the translaton of films, the popularity of dubbed versions of animated films and feature films for young audiences generated by Shrek did not permeate into other film genres and did not bring about any major changes in AVT techniques applied in Poland. Eight years after the premiere of Shrek, most television productions are still broadcast with voiceover, DVD releases include both subtitling and voiceover versions, while most films screened in cinemas are only subtitled. Economic factors that determine the preponderance of voiceover may be less crucial nowadays than they were some decades ago, especially for non-public broadcasters. It seems, therefore, that old translation traditions and viewing habits die hard in Poland.

\section{References}

Agost, Rosa (2004) "Translation in bilingual contexts. Different norms in dubbing translation", in Pilar Orero (ed.) Topics in Audiovisual Translation. Amsterdam and Philadelphia: John Benjamins, 63-82.

Bogucki, Łukasz (2004) "The constraint of relevance in subtitling". The Journal of Specialised Translation 1: 71-88. www.jostrans.org/issue01/art_bogucki_en.pdf

Chaume, Frederic (2003) Doblatge i subtitulació per a la TV. Vic: Eumo Editorial.

Chaume, Frederic (2004) "Synchronization in dubbing. A translational approach", in Pilar Orero (ed.) Topics in Audiovisual Translation. Amsterdam and Philadelphia: John Benjamins, 35-52.

Coleridge, Samuel T. (1817/1985) Biographia Literaria: Biographical Sketches of My Literary Life and Opinions, Princeton: Princeton University Press.

Díaz Cintas, Jorge (2004) "In search of a theoretical framework for the study of audiovisual translation", in Pilar Orero (ed.) Topics in Audiovisual Translation. Amsterdam and Philadelphia: John Benjamins, 21-34.

Dries, Josephine (1995) "Breaking Eastern European barriers". Sequentia 2 (4): 5-6.

Even-Zohar, Itamar (1978) "The position of translated literature within the literary polysystem", in James Holmes, José Lambert and Raymond van den Broeck (eds) Literature and Translation. Leuven: ACCO, 117-27.

Garcarz, Michał (2006) "Polskie tłumaczenia filmowe". The Journal of Specialised Translation 5: 110-9. www.jostrans.org/issue05/art garcarz.pdf

Johnson, Steven (2005) Everything Bad is Good for You. How Popular Culture is Making Us Smarter, London: Penguin.

Luyken, Georg-Michael, Thomas Herbst, Jo Langham-Brown, Helen Reid and Hermann Spinhof (1991) Overcoming Language Barriers in Television: Dubbing and Subtitling for the European Audience, Manchester: European Institute for the Media.

Romero Fresco, Pablo (2006) "The Spanish dubbese: A case of (un)idiomatic Friends". The Journal of Specialised Translation 6: 134-51. 
This is an Author's Accepted Manuscript of a chapter in Jorge Diaz Cintas, Anna Matamala, Joselia Neves (eds.) New Insights into Audiovisual Translation and Media Accessibility. Media for All 2. Amsterdam / New York: Rodopi, 123-136, available here:

http://www.rodopi.nl/functions/search.asp?Bookld=ATS+33

www.jostrans.org/issue06/art romero fresco.pdf

Tomaszkiewicz, Teresa (2006) Przekład audiowizualny, Warszawa: PWN.

Whitman, Candace (1992) Through the Dubbing Glass. Frankfurt: Peter Lang.

Wierzbięta, Bartosz (2002) An interview.

www.interia.pl

Wojtowicz, Grzegorz (2002) "Bardzo dobre dialogi są. Rozmowa z Bartoszem Wierzbiętą". www.stopklatka.pl

Zabalbeascoa, Patrick (1993) Developing Translation Studies to Better Account for Audiovisual Texts and Other New Forms of Text Production. Lleida: University of Lleida. PhD Thesis.

Zabalbeascoa, Patrick (1997) "Dubbing and the nonverbal dimension of translation" in: Fernando Poyatos (ed.) Nonverbal Communication and Translation, Amsterdam/Philadelphia: John Benjamins, 327-42. 